Notre Dame Law School

NDLScholarship

Journal Articles

Publications

2000

\title{
What O'Clock I Say: Juridical Epistemics and the Magisterium of the Church
}

Robert E. Rodes

Notre Dame Law School, robert.e.rodes.1@nd.edu

Follow this and additional works at: https://scholarship.law.nd.edu/law_faculty_scholarship

Part of the Religion Law Commons

\section{Recommended Citation}

Robert E. Rodes, What O'Clock I Say: Juridical Epistemics and the Magisterium of the Church, 14 J. L. \& Religion 285 (1999-2000). Available at: https://scholarship.law.nd.edu/law_faculty_scholarship/720

This Article is brought to you for free and open access by the Publications at NDLScholarship. It has been accepted for inclusion in Journal Articles by an authorized administrator of NDLScholarship. For more information, please contact lawdr@nd.edu. 


\title{
WHAT O'CLOCK I SAY: JURIDICAL EPISTEMICS AND THE MAGISTERIUM OF THE CHURCH
}

\author{
Robert E. Rodes, $J r^{\dagger}$
}

Petruchio: I will not go today; and ere I do It shall be what o'clock I say it is.

Hortensio: Why, so, this gallant will command the sun. ${ }^{1}$

$$
* * *
$$

Scrope, C.J.: I remember it well, but I can have no knowledge of it in my capacity as judge. ${ }^{2}$

$$
* * *
$$

The Catholic Church claims a wide authority to make pronouncements on faith and morals, and have them respected by members of the church. The nature and extent of the respect to be accorded them is subject to considerable debate, some of it both extensive and acrimonious. It is claimed, to be sure, that certain pronouncements are infallible; if so, they are obviously beyond debate. But for most pronouncements no such claim is made. Furthermore, the question whether a given pronouncement is infallible or not is itself debatable, and can generally not be infallibly resolved.

We are confronted, therefore, with an array of assertions of varying provenance to which we are expected to give some measure of credence, even though we have no guarantee that they are true, or even that their authors are particularly wellinformed. They take their authority from that of the church, which in its corporate capacity is the repository of God's Revelation, and the beneficiary of His guidance.

$\dagger$ Paul J. Schierl/Fort Howard Corporation Professor of Legal Ethics, Notre Dame Law School.

1. The Taming of the Shrew, Act IV, Scene 3 .

2. Eyre of Northamptonshire 1329-1330 at 238 i (Selden Soc. xcvii). An ex-sheriff, accused of allowing a prisoner to escape, has reminded Scrope that he was previously cleared of the same charge before Scrope himself in the King's Bench. But personal recollection will not serve for an acquittal in the Eyre. The accused must go to Westminster and get the record from the King's Bench. Compare St. Thomas Aquinas's argument in $S$. Theol., II, II, q. 64, article 6 that a judge must condemn an accused to death if the evidence indicates that he is guilty, even if the judge has personal knowledge that he is innocent. 
The prelates, officials, and church bodies that exercise this authority necessarily do so under legal forms. Divinely guided or not, the church is an institution, and it is legal form that determines whether and in what way the words and deeds of natural persons are to be attributed to an institution. It is unfortunate, therefore, that the ongoing debate over the force and effect of the church's doctrinal pronouncements has elicited so little analysis of their legal form. Analogous pronouncements of secular authorities have been analyzed more fully. They are dealt with by legal scholars under a range of titles including Agency, Constitutional Law, Administrative Law, Corporations, and sometimes even Torts and Criminal Law. My object in this article is to locate the pronouncements of the church on faith and morals in the context provided by this legal material, and see what light that context can shed on them.

\section{Three Kinds of Pronouncement}

It might seem at first blush that no comparison is possible: the state does not make doctrinal pronouncements as the church does. On the other hand, the state does come up with pronouncements which, like those of the church, determine that such-and-such is-or is deemed to be-the case, and that particular affairs shall be dealt with accordingly. These are far from a majority of legal enactments, but there are enough of them to provide the material for a comparative analysis.

Factual pronouncements in the law come in three distinct categories, different in provenance, in purpose, and in effect. I will call them epistemic, normative, and constitutive. Epistemic pronouncements call for acting on the basis of something being the case because of good faith investigation and determination that it is in fact the case. The findings of fact in a judicial decision or in the preamble of a statute are of this kind. ${ }^{3}$ Normative pronouncements seek to accomplish their purpose by treating something as being the case whether it is so or not. Estoppels,

3. If a fact is specifically found by a court or jury after a trial, the parties to the litigation are generally precluded from asserting in another litigation that that fact is not the case. Findings of fact in the preamble of a statute are used by courts either to interpret the statute or to uphold its validity. A famous example is Block $v$ Hirsch, 256 US 135, 194 (1921), in which a finding by Congress as to the effect of the First World War on housing in the District of Columbia was used to uphold rent regulation that the Court as it was then constituted would otherwise have invalidated. 
irrebuttable presumptions, and constructive trusts are examples. ${ }^{4}$ Constitutive pronouncements actually cause something to be the case-some state of affairs defined by the law. The county line, for instance, is always wherever the legislature says it is. Or, if the President, with the advice and consent of the Senate, appoints Smith a judge, it will immediately be the case that Smith is a judge.

It is possible for a pronouncement to be effective in one of these categories when it would be impossible or illegal in either of the others. Here are three examples, one from each category:

\section{Epistemic:}

During the First World War, a German submarine sank a plainly marked British hospital ship. After the war, the captain was put on trial. His defense was that the German Admiralty had informed him that the British were marking their troopships as hospital ships, and therefore he should not regard ships marked in this way as immune from attack. This defense was held good. ${ }^{5}$ While the captain had no right to sink hospital ships on superior orders, he was entitled to believe his superiors regarding a matter of empirical fact that he had no way of verifying. In other words, while the Admiralty had no normative authority-they could not order the sinking of a hospital ship-and no constitutive authority-they could not make a hospital ship into a legitimate target-they did have epistemic authority. Submarine commanders could give their pronouncements epistemic effect.

\section{Normative:}

From May through December, 1862, General Benjamin Butler was in command of the federal troops occupying New Orleans. The population were generally hostile, and the women took particular pains to show their hostility. To deal with the situation, Butler issued the following order:

4. The usual estoppel occurs when $A$ is so far responsible for a factual error on B's part as to be precluded from asserting the true fact against B. A presumption is a fact that requires no evidence to establish it. If evidence to the contrary will be received and considered, the presumption is rebuttable; if not, it is irrebuttable or conclusive. A constructive trust arises when $A$ has acquired property from $B$ by fraud or duress, and is therefore made to treat it as if he were B's trustee.

5. The Dover Castle, 16 Am J of Intl L 704 (1921). 
Whenever any female shall, by word, or gesture, or movement, insult or show contempt for any officer or soldier of the United States, she shall be regarded and held liable to be treated as a woman of the town plying her avocation. ${ }^{6}$

This order was purely normative. Butler had-or claimed to have-authority to control the behavior of the local populace toward his troops, and his order was adopted as a way of doing so. He claimed no epistemic authority: no authority to investigate and adjudge whether a particular woman was or was not a prostitute. And he certainly did not claim to make any woman a prostitute who was not one already.

\section{Constitutive:}

During the Second World War, Congress passed an act calling for all clocks to be set ahead an hour so as to provide additional light for the war effort. A certain bar in Wisconsin remained open until 2 A.M. Central War Time, and the proprietor was prosecuted for violating a state statute requiring such bars to close at one. He defended himself on the basis of other state statutes, enacted before the war; according to those statutes, it was one o'clock when he closed. But the Supreme Court of Wisconsin said that the object of all laws setting time is uniformity, and it cannot be supposed that the Wisconsin legislature intended to have state and federal affairs run on different times. ${ }^{7}$ The law involved in this case is clearly constitutive. Federal time statutes do contain provisions that federal agencies and persons engaged in interstate commerce shall govern themselves accordingly, but Congress had neither the authority nor the inclination to tell bars in Wisconsin when to close. The law cannot be normative, because it has effect beyond the normative reach of the power that enacted it. Nor is it epistemic. "Real" time is sun time. It varies by four minutes with each degree of longitude, and changes incrementally with every step you take east or west. Anyone with a sun dial can make a better epistemic determination of real time than any legislature can. The custom of "standard" time, changing in one hour

6. Virtually all Civil War histories tell this story, as does Butler's entry in the Dictionary of American Biography, Vol. II Part l at 357 (Scribner, 1957).

7. State $v$ Badolati, 241 Wis 496, 6 NW2d 220, 143 ALR 1234 (1942). 
increments with every fifteen degrees of longitude, was first adopted by railroads in 1883 , and then taken up by state statutes, and finally by a federal statute in $1918 .^{8}$ The evolution in other countries was similar. In every place, therefore, the time in legal effect is chosen, not discerned.

Particular agencies, as shown in these examples, may have a broader authority over one category of pronouncement than over the others. But a legal system taken as a whole will have all three categories available, and will give them different kinds of work to do.

Constitutive forms are generally used for delegation of authority, assignment of personal status, and formalization of transactions. I referred to the drawing of boundaries between political subdivisions and to the appointment of judges. A law enumerating the powers of an administrative agency would be another example. The Thirteenth and Fourteenth Amendments to the Federal Constitution are examples of assigning status, freedom in the one case, citizenship in the other. Examples involving transactions include the Statute of Frauds," the requirement of two witnesses for a will, the rule that minors are not bound by their contracts, and the requirement of licenses for marriages. The significant characteristic of a constitutive pronouncement is that it is self-executing. When the legislature says that you cannot marry without a license, it is in fact the case that you cannot marry without a license. You can go through the ceremony, but you will not be married. On the other hand, when the legislature says that you cannot drive a car without a license, that is not in fact the case. If you drive without a license you may get arrested, but until you are caught you can still drive.

Normative pronouncements are used where the law embraces some value that calls for acting as if something is the case whether or not it is in fact so. They cover a wide range of concerns, from the provision in Rule 15 of the Federal Rules of Civil Procedure for treating issues not raised by the pleadings as if they were so raised to the traditional rule of family law that presumes a woman's husband to be the father of her child. In the one case, the law implements a policy of not letting litigations be lost on pleading errors, in the other a policy of promoting family

8. Ann, 143 ALR 1238 (1943).

9. The Statute of Frauds makes certain classes of oral contracts unenforceable. 
stability. As Justice Scalia put it in the latter case: "Of course the conclusive presumption not only expresses the state's policy but also furthers it, excluding inquires into the child's paternity that would be destructive of family integrity and privacy."10

Epistemic pronouncements arise from a genuine purpose of ascertaining the truth and acting accordingly, but without unduly straining the resources of the legal system for informing itself. Res judicata and administrative finality are examples. ${ }^{11}$ So are most rebuttable presumptions. While most conclusive or irrebuttable presumptions are normative, a few of these are epistemic also. They are used where the fact presumed is so likely to be the case that drawing it into question will make more trouble than it is worth. The most common example is the statutory presumption that certain family members are dependent on a wage earner for support. ${ }^{12}$ Such presumptions are more questionable now than they were a generation back, and some of them have been declared unconstitutional. In 1977, for instance, the Supreme Court struck down a provision of the Social Security Act that gave benefits automatically to widows, but gave them to widowers only on a showing of actual dependency. ${ }^{13}$ Four justices thought that widows were so often dependent and widowers so seldom that the distinction was empirically justified, but the other five found it to be an impermissible gender discrimination.

\section{CASe ANalysis}

Often, the three categories are intertwined or ambiguous, so that they have to be sorted out or characterized before a case can be decided. For example, the federal legislation regarding loss of citizenship has at one time or another embraced all three of our categories, and it has taken several decisions of the Supreme Court to give each its proper scope. Until 1958, the applicable provisions were partly constitutive and partly normative. ${ }^{14}$ The

10. Michael H. $v$ Gerald D. , 491 US 110, 120 (1989).

11. Res judicata is a doctrine that precludes relitigating a matter once decided by a court. Administrative finality does the same for a matter. decided by an administrative agency.

12. See, for instance, the Ind Workers' Compensation Act, Ind Code 22-3-3-19; Wilson $v$ LaPorte Gas \& Electric Company, 107 Ind App 21, 22 NE2d 882 (1939).

13. Califano $v$ Goldfarb, 430 US 99 (1977)

14. 8 US Code 1481 . The provision on voting was repealed in 1978. 
constitutive part made loss of citizenship follow automatically from certain acts such as enlisting in a foreign army or voting in a foreign election. The normative part made loss of citizenship part of the punishment to be imposed by a court martial on a wartime deserter. In 1958, the constitutive part was upheld against constitutional objection in Perez $v$. Brownell, ${ }^{15}$ while the normative part was stricken down in Trop v. Dulles. ${ }^{16}$

Justice Frankfurter, speaking for the majority in Perez, said that dual nationality was a source of conflict with other nations, and Congress, in the exercise of its power over foreign relations, could adopt this measure to deal with the problem. The constitutive provision took effect automatically when the problem arose, and afforded a built-in solution. Chief Justice Warren and Justice Douglas both wrote dissenting opinions to the effect that the Fourteenth Amendment, by making citizens of "all persons born or naturalized in the United States and subject to the jurisdiction thereof," deprived Congress of any power to take away the citizenship of anyone who did not choose deliberately to relinquish it. Douglas is particularly clear on the constitutive character of the amendment: "We deal here with the right of citizenship created by the Constitution .... What the Constitution grants the Constitution can take away. But there is not a word in that document that covers expatriation." 17

The normative provision in Trop, unlike the constitutive provision in Perez, had no built-in relation to the situation it addressed. It treated the act of desertion as an abandonment of national allegiance even if in fact it was nothing of the kind. As Warren put it in his plurality opinion:

The purpose of taking away citizenship from a convicted deserter is simply to punish him. There is no other legitimate purpose that the statute could serve. Denationalization in this case is not even claimed to be a means of solving international problems, as was argued in Perez. ${ }^{18}$

Having determined that the expatriation was a punishment, Warren found that it was a cruel and unusual one forbidden by the Eighth Amendment. Frankfurter, dissenting, found the

15. Perez v Brownell, 356 US 44 (1958).

16. Trop v Dulles, 356 US 86 (1958).

17. Perez, 356 US at 79.

18. Trop, 356 US at 97. 
provision to be a legitimate exercise of the power of Congress to wage war, and therefore not to constitute punishment within the meaning of the Eighth Amendment. ${ }^{19}$

Justice Brennan, the only justice in the majority in both cases, relied a good deal on the constitutive character of the expatriation in Perez versus the normative character of that in Trop. On the one hand, under the constitutive provision:

Expatriation ... has the advantage of acting automatically, for the very act of casting the ballot is the act of denationalization, which could have the effect of cutting off responsibility for the consequences. If a foreign government objects, the answer should be conclusive-the voter is no longer one of ours. Harsh as the consequences may be to the individual concerned, Congress has ordained the loss of citizenship simultaneously with the act of voting because Congress might reasonably believe that in these circumstances there is no acceptable alternative to expatriation as a means of avoiding possible embarrassments to our relations with foreign nations. ${ }^{20}$

On the other hand, under the normative provision:

It is difficult, indeed, to see how expatriation of the deserter helps wage war except as it performs that function when imposed as a punishment. It is obvious that expatriation cannot in any wise avoid the harm apprehended by Congress. After the act of desertion, only punishment can follow, for the harm has been done. The deserter, moreover, does not cease to be an American citizen at the moment he deserts. Indeed, even conviction does not necessarily effect his expatriation, for dishonorable discharge is the condition precedent to loss of citizenship. Therefore, if expatriation is made a consequence of: desertion, it must stand together with death and imprisonment-as a form of punishment. ${ }^{21}$

Having drawn this distinction, Brennan relied on the general unreasonableness of the normative provision, rather than on the Eighth Amendment, to invalidate it.

In Afroyim v. Rusk (1967), ${ }^{22}$ the Court overruled Perez, relying for the most part on the constitutive force of the Fourteenth

19. Id at 114.

20. Id at $105,106$.

21. Id at $105,109-10$.

22. Afroyim $v$ Rusk, 387 US 253 (1967). 
Amendment as Warren and Douglas had interpreted it in their dissenting opinions. Since the Amendment says that anyone is a citizen who is born or naturalized in the United States and subject to the jurisdiction thereof, no one can be denationalized except by a voluntary act. This decision invalidated the whole statutory list of denationalizing actions insofar as it purported to have either constitutive or normative effect. But the list appears still to have epistemic effect. The listed actions can be taken as evidence of the voluntary relinquishment that is the only way a person once a citizen can cease to be one after Afroyim. How much evidentiary effect such actions have is in some debate in the cases, but the Supreme Court has held that they may be considered "highly persuasive," and that Congress may adjust the burden of proof regarding them without infringing on substantive rights. ${ }^{23}$ In short, according to the Court, Congress has more authority to address this subject with epistemic effect than with either constitutive or normative effect.

In other cases, a legislative body may have normative power where it would not have epistemic. This is the upshot of a short opinion by Justice Holmes in the case of Ferry $v$. Ramsey (1928). ${ }^{24} \mathrm{~A}$ Kansas statute provided that bank directors would be personally liable if they allowed their bank to accept deposits when they knew it was insolvent, and that if their bank was in fact insolvent they would be presumed to know. A director attacked this statute as violating due process by presuming something (i.e., knowledge) to be the case on tive basis of an inference that had no support in reality. Holmes brushed this objection aside, saying that the state could if it chose make directors liable regardless of knowledge. It followed that by requiring knowledge and then presuming it the state was being less strict than it needed to be, and the director had no ground for complaint. In other words, the statute, though epistemically infirm, could be sustained as an exercise of normative authority.

Ferry, like a number of Holmes decisions, proved not to be subtle enough for the long haul. In Tot $v$. United States (1943), ${ }^{25}$ the Supreme Court invalidated a federal statute making it a crime for a convicted felon to have a gun that had been shipped in interstate commerce since the enactment of the statute, and

23. Vance $v$ Terrazas, 444 US 252 (1980).

24. Ferry $v$ Ramsey, 277 US 88 (1928).

25. Tot $v$ United States, 319 US 4631519 (1943). 
creating a presumption that any gun found in the possession of a convicted felon had been so shipped. The Court accepted the argument that an inference with no empirical basis violated due process, but refused to do what Holmes had done and allow the epistemic weakness to be made up for normatively. Granted, Congress might have made it a crime for a convicted felon to have any gun at all, but that is not what they chose to do. This statute, like the one in Ferry, failed epistemically where it might have succeeded normatively. But this Court, unlike the Ferry Court, would not shift the statute from one category to the other in order to save it.

In administrative law, the distinction between the normative and the epistemic affects the handling of what are called mixed questions of law and fact. Obviously, a proposition that such and such is the case can be either one of law or one of fact. I have tried to show here that it can also be either epistemic or normative. In many cases, it is the latter distinction that structures the debate over the finality to be accorded determinations by administrators, or the extent to which such determinations are reviewable in court. A classic case on the subject is NLRB $v$. Hearst Publications, ${ }^{26}$ decided by the Supreme Court in 1944. The issue was whether certain news vendors were "employees" of the publishers whose papers they sold, and, as such, entitled to collective bargaining under federal law. The National Labor Relations Board had decided that they were, and the reviewing court had decided the opposite. The Supreme Court reversed the lower court and upheld the Board.

There was available at the time a great body of precedent on the subject of who is or is not an "employee," but most of it involved vicarious liability-that is, the application of the principle that an employer is liable for the torts of an employee, but not for those of an "independent contractor." It was reasonably clear that under these precedents the news vendors would have been independent contractors. Had one of them negligently placed a stack of newspapers where a passerby would trip over them, the publisher would not have been liable. The Board did not deny that that was the case, but they decided that the word "employee" in the statute they were given to administer should be interpreted as referring not to such workers as would

26. NLRB v Hearst Publications, 322 US 111 (1944). 
be sources of tort liability, but to such workers as needed the protection the statute provided. Justice Rutledge, speaking for all but one of his colleagues, agreed with the Board's approach:

Unless the common-law tests are to be imported and made exclusively controlling, without regard to the statute's purposes, it cannot be irrelevant that the particular workers in these cases are subject, as a matter of economic fact, to the evils the statute was designed to eradicate $\ldots{ }^{27}$

And the determination of what workers are subject to the evils in question, and therefore to be regarded as employees for purposes of the Labor Relations Act, is committed by statute to the discretion of the Board.

Rutledge's decision treats the question of whether it is the case that the news vendors are employees as a normative one. It is to be answered in accordance with whether an affirmative answer will implement legislative policy. The answer is up to the Board because the task of implementing this particular piece of legislative policy is assigned by statute to the Board. The normative character of the decision as Rutledge sees it is emphasized by the epistemic character that Justice Roberts in his dissenting opinion says that the decision ought to have:

I think it plain that newsboys are not "employees" of the respondents within the meaning of the National Labor Relations Act. When Congress ... said "The term 'employee' shall include any employee, ..." it stated as clearly as language could do it that the provisions of the Act were to extend to those who, as a result of decades of tradition which had become part of the common understanding of our people, bear the named relationship. ${ }^{28}$

In Hearst, the authority to make the decision was assigned to the agency because it was normative whereas if it had been epistemic it would have been assigned to the court. In other cases, the opposite assignment is made. O'Keefe v. Smith, Hinchman \& Grylls $(1965)^{29}$ involved a man who drowned in a recreational weekend boating accident while he was in Korea doing a job for a United States government contractor. The Deputy Commissioner administering the federal compensation law awarded a death benefit to the man's family on the theory that his death was job

27. Id at 127.

28. Id at 135 .

29. O'Keefe $v$ Smilt, Hinchman and Grylls Assoc, Inc., 380 US 359 (1965). 
related. The Deputy Commissioner's reasoning is not explained at length in the report; but he presumably felt that anything that happened to an overseas employee from the time he left the United States until the time he returned was connected with the job. A majority of the Supreme Court upheld the decision, simply on the ground that it represented a rational inference from the undisputed facts: "The rule of judicial review has therefore emerged that the inferences drawn by the Deputy Commissioner are to be accepted unless they are irrational or "unsupported by substantial evidence on the record . . as a whole:" 30 . This language points up the epistemic character of the Deputy Commissioner's determination by referring to it as an inference.

The dissent regarded the same determination as normative, and therefore objectionable because it exceeded the normative authority of the Deputy Commissioner:

The cases in which this limited review of the administrator's decision is appropriate are those in which one application of the statute to the external facts of the case effectuates the judicially recognizable purposes of the statute as well as another .... In the case before us, the Deputy Commissioner's ruling is not consistent with the statutory purpose. $^{31}$

My point is not that the characterization determined the result; it did not. The majority could have found that calling weekend recreation job related was irrational and therefore outside the epistemic authority of the Deputy Commissioner. Conversely, the dissenters could have found that full-time coverage for overseas workers was within the normative authority of the Deputy Commissioner because it could reasonably be regarded as effectuating the purposes of the compensation law. My point is simply that the characterization one way or the other structured the debate, and will generally do so in cases of this kind.

Hearst and O'Keefe both involve administrative adjudication. Administrative agencies have also a rule-making function-one which some possess more broadly or exercise more vigorously than others. Rules, like statutes, are generally made on the basis of extensive investigation of the relevant facts; even so, they are

30. Id at 362 .

31. Id at 365, 368-69. 
generally considered normative in their effects. Within the factual situation developed, the agency has policies to implement and choices to make in implementing them. The decisions arrived at are chosen, not discerned. But in one case, Heckler v. Campbell (1983), ${ }^{32}$ the Supreme Court upheld a piece of rule-making with purely epistemic effect.

The Social Security Act provides pensions for disabled workers. The Secretary of Health and Human Services is instructed to find that workers are disabled only if, considering their age, education, and work experience, as well as their level of disability, there is no work in the national economy that they can do. In other words, the national economy may have jobs for paraplegic lawyers, but not for paraplegic illiterates. As the Secretary saw it, she or her subordinates had two decisions to make, one regarding the individual claimant, the other regarding the state of the national economy. The first was necessarily casespecific, but the second would be the same in every case. Accordingly, she developed and promulgated by regulation a set of guidelines to be used in all cases to determine what kind of work existed in the national economy. Campbell, the claimant in this case, argued that the Secretary should be required to bring forward her assertions about the national economy in a casespecific form, so that contrary evidence could be introduced by the claimant and considered by the Administrative Law Judge in each case. The Supreme Court disagreed. It held that since the same national economy is involved in every case, a single regulation, made after a single investigation and consideration of evidence, has as much assurance of epistemic accuracy as is required. This is the clearest example I know of a strictly legislative disposition with purely epistemic effect. As such, it comes closest to some of the ecclesiastical material we are about to consider.

\section{PRINCIPLES OF APPLiCATION}

Before turning to the church, though, let us look at a few principles that apply to the secular material we have been considering, and may, with a few qualifications, apply to the church as well. One such principle is general: If there has been an authoritative pronouncement to the effect that such and such

32. Heckler $v$ Campbell, 461 US 458 (1983). 
is (or will be deemed to be) the case, then affairs subject to the authority making the pronouncement will be conducted on that assumption. Other principles depend on which of the three categories that we have been considering applies to a given pronouncement.

Let us look first at the binding force of the different pronouncements, the obligations they impose. There is a general, albeit limited, moral obligation to obey the law, and normative pronouncements invoke that obligation. They also invoke the general principle that sanctions will be imposed on those who do not obey. In fact, in many cases, the state of affairs recognized by the pronouncement is itself a sanction, as in General Butler's "woman of the town" order.

Constitutive pronouncements, as we have seen, are selfexecuting. If they are unconditional-as with a drawing of boundaries or an adoption of standard time-the only obligation they impose is whatever obligation arises from the state of affairs they announce-as in the case of the proprietor's duty to close his bar at one. On the other hand, conditional constitutive pronouncements, such as the provision that anyone who votes in a foreign election ceases to be an American citizen, may never be effective because it may never be known who fulfills the condition. Just after the Second World War, Americans living in certain foreign countries where they were eligible to vote because of their national origins were encouraged to do so in order to insure governments favorable to American policy. All of them became aliens, and remained so until the Afroyim case restored their citizenship, ${ }^{33}$ but many of them were quite unaware of either transition.

For people who are directly subject to the author of an epistemic pronouncement, it has about the same binding force as a normative pronouncement would. If the relevant agencies find that your airplane is unsafe, you will not be allowed to fly it; if they find that your food additive causes cancer, you will not be allowed to sell it. But beyond these normative effects, you may give the epistemic pronouncement further effect if you believe the author to be well informed. The finding that an airplane or a food additive is safe may not require you to fly in the one or eat the other, but it may lead you to feel safe in doing so. Also, as in

33. Ann, 2 LEd2d 1917 (1958). 
the case of the submarine captain, good faith reliance on an authoritative epistemic determination may justify actions which on the true facts would be unlawful, immoral, or both.

The excuses available for noncompliance also differ among the three categories. Normative pronouncements are subject to the same excuses as other norms. I would presume, for instance, that Butler's order would not have been applied to a woman who insulted a Union soldier in response to an indecent proposal by the soldier.

In the case of a constitutive pronouncement, it is hard to think of excuses for noncompliance, because it is hard to see compliance as a meaningful concept. The authoritative statement that such and such is the case in fact causes it to be the case. One can be unaware of its being the case, just as one can be unaware of any other fact, and that unawareness may have legal consequences. But it would be stretching a point to speak of not complying with the law that made it a fact.

Nor is it altogether accurate to speak of not complying with an epistemic pronouncement. The fact declared by such a pronouncement, like any other fact, may be subject to estoppel; i.e., for some reason the law may forbid a person to take advantage of its being the case. More important, it is possible for an epistemic pronouncement, unlike the others, to be erroneous: what it says to be true may in fact be false. If the error is clear enough, it may justify disregarding the pronouncement. You can probably avoid treating something as true if you have strong enough evidence that it is false. On the other hand, officials do not readily accept the possibility of being in error: the evidentiary requirements may be substantial.

Opposition to constitutive or normative pronouncements is generally political. Whether by electioneering, protest marches, or throwing rotten tomatoes, if we wish to avoid a constitutive pronouncement, we must get it repealed, and if we wish to avoid a normative pronouncement, we must at least get it not enforced. But in the case of an epistemic pronouncement, we must show that it is not the case. Political action may lead to the election or appointment of authorities more open to that possibility than their predecessors were, but the actual epistemic determination cannot be political. 


\section{Pronouncements of THE ChurCH}

The church has constitutive and normative authority over the sacraments, the liturgy, the deployment of its clergy and other personnel, the administration of its property and revenues, and the religious practices of its members. It also has epistemic authority over questions of faith and morals. The first two categories are rather like comparable secular authority, although there are one or two peculiarities, as we shall see. The epistemic authority of the church is also similar in many ways to its secular analogue, but it is broader both in scope and in significance. Because of its mandate to teach morality, the church has an epistemic authority in many areas to which the authority of secular law extends only normatively or not at all. The proposition that the use of contraceptives is morally unacceptable may be true or may be false. ${ }^{34}$ Church officials who try to determine whether it is true or false and then let us know are doing no more than their job. But they would not be doing their job if, having decided that the practice is not morally unacceptable, they told us to abstain from it anyway. Their epistemic authority may extend to the marital bedroom, but their normative authority does not.

Also, the epistemic authority of the church extends beyond the realm of doing and not doing (as the theologians say, of praxis). While we are told that faith without works is dead, works without faith are not much recommended either. The church, unlike the state, has a substantial set of epistemic pronouncements that we are not expected immediately to act on, but simply to believe. Believing them is not without practical consequences, as we eventually learn, but the consequences are not necessarily present to us when we accept the pronouncements. ${ }^{35}$

34. Note how that proposition differs in form from other things that might be said on the subject. "Don't use contraceptives" would be normative, but it would not be a pronouncement that this or that is or will be treated as being the case. So it is not within the scope of this article. "Anyone who uses contraceptives shall be considered an adulterer" would be a normative pronouncement within our scope. "The use of contraceptives is unnatural" would not be a proposition regarding morality, -although it might be offered in support of such a proposition.

35. William Stringfellow, a great lawyer and theologian, once caused considerable excitement by saying that the civil rights movement is about baptism. Will D. Campbell, Brother to a Dragonfly 230 (Continuum, 1977). His point was not to exclude the unbaptized, but to derive from the theology of the sacrament a call to solidarity transcending the 
The unique epistemic authority of the church goes by the name of magisterium. This use of the term evidently originated in the nineteenth century. ${ }^{36}$ It is coordinate with dominium, the authority of owners over their property, and imperium, the authority of rulers over their subjects. I shall try in the rest of this article to isolate this phenomenon from other manifestations of ecclesiastical authority and see what it looks like.

In the medieval period, the church's legal structure took on a form of which it retains a good deal even today. The form was characterized by a couple of serious confusions among the three categories of pronouncement we have been considering. In the first place, the system developed a theoretical sophistication that greatly outran its capacity for either gathering information or enforcing its mandates. As a result, it fell into a habit of articulating what should have been normative dispositions in constitutive form. ${ }^{37}$ Having decided that a priest should not be the pastor of two parishes, and having no adequate way of finding out whether the priest showing up to be put in charge of a parish was already in charge of another (the history of centralized record keeping is an important one, but this is not the place for it), the authorities provided that his first position, if any, would become ipso facto vacant when he was put into the second. Having decided that a man should not marry the sister of his cast-off mistress, and having no way of learning of the prior liaison with the prospective sister-in-law unless the parties admitted it, they made the marriage ipso facto void if there had been such a liaison. Provisions of this kind with constitutive effects of which most people might be quite unaware introduced great swathes of uncertainty into personal status and the tenure of ecclesiastical offices without having much effect at all on compliance.

Particularly problematic in this regard was the broad range of situations in which people could incur excommunication without anyone (themselves included) knowing that they had done so. This form of constitutive sanction became so prevalent that one bishop actually had corpses dug up on the theory that the

\footnotetext{
level playing field. On reflection, I believe he was right, but I had accepted the same theology for a long time without arriving at this particular consequence.

36. The earliest reference in the Oxford English Dictionary to the use of the word in this sense is to the Dublin Rev 422 (April 1866).

37. See Robert E. Rodes Jr., Ecclesiastical Administration in Medieval England 79-84 (U Notre Dame Press, 1977).
} 
deceased had incurred excommunication by being buried in the wrong place. ${ }^{38}$ Any competent canonist would have said the bishop was going too far, but the chances of being inadvertently excommunicated were significant. And the chances of a clergyman incurring the comparable state of irregularity, excluding him from the exercise of the ministry, were, according to one commentator, better than even. ${ }^{39}$ Until quite recently, the formula for absolution in the confessional responded to this situation by including absolution from excommunication and other censures "to the extent of my power and your need." In other words, one uncertain constitutive effect was uncertainly canceled out by another.

I believe this proliferation of constitutive pronouncements had a significant effect on the development of Catholic doctrine regarding conscience. Looking at a widespread and severe sanction with no way of determining who had incurred it, church people naturally drew on a subjective consideration to fill the gap. Until the constitutive sanction against you was confirmed by a normative pronouncement-e.g., a judicial or administrative act referring to you by name-you were not bound by it unless your conscience told you that you had done something wrong to incur it. I think a good deal of learning about the resolution of doubt, the distinction between the internal and the external forum, and the primacy of conscience takes its origin from this situation.

Another longstanding confusion arises from the practice of setting forth epistemic pronouncements in normative form. The tendency to regard misbelievers as evil rather than as honestly mistaken is an old one, not without support in the New Testament: St. Paul's instructions to Timothy and Titus on how to run their churches do not leave much room for respecting the good faith of the opposition. Also, with the integration of the church into the moribund Roman state, bishops and ecclesiastical synods began adopting the legislative style of the civil authorities, who became more and more vituperative as they became less and less in control. Referring to opponents as madmen or monsters of depravity became no more than customary rhetoric for the doctrinal pronouncements of the period. Add to this development the need of the early church to define itself in a

38. Parry, ed, Registrum Johannis de Trillek, Episcopi Herefordensis 105, 120 (viii Canterbury \& York Soc'y, 1912).

39. Christopher St. Germain, The Addicions of Salem and Byzance fol. 5 (London, 1534). 
welter of religions new and old, and the need of the medieval church to control its personnel and resources, and it becomes understandable that authoritative pronouncements on doctrine have often seemed more concerned with excluding error than with witnessing truth, and perhaps more concerned with excluding erring people than with excluding erroneous doctrine.

So it is that the 1918 Code of Canon Law, in force until 1983, claims for doctrinal pronouncements a normativity considerably beyond their epistemic scope:

It is not enough to avoid heretical depravity; one must also diligently flee those errors that more or less lead up to it. Therefore, all must observe (servare) the constitutions and decrees by which such depraved opinions are proscribed and forbidden by the Holy See (can. 1324-my translation).

The 1983 Code avoids the vituperation of the earlier material, but it is no less normative in form: "All the Christian faithful are obliged to observe (again, servare) the constitutions and decrees which the legitimate authority of the Church issues in order to propose doctrine and proscribe erroneous opinions" (can. 754C.L.S.A. translation). The persistence of these normative patterns means that even today people will tend to see the church's doctrinal pronouncements less as informing them than as ordering them about.

Confusion of categories probably does not create any controversies in the church, but it does structure the way they will be conducted when they occur. I will not pursue any particular controversy here, but a few words about some of them may indicate what $I$ have in mind.

1. Humanae Vitae,${ }^{40}$ the papal document condemning the use of contraceptives, if it is not epistemic, is beyond the competence of its author. It occupies a realm in which the church has authority to teach, but not to legislate. Nevertheless, most accounts of how it came to be adopted indicate that one of the pope's main concerns was the common good of the church. ${ }^{41}$ Much of the criticism of the

40. (Wash, Nat'l Council of Catholic Bishops, 1968).

41. It is generally believed that the pope rested his decision on the considerations set forth in the minority report of the papal commission on the subject. That report is published in D. Callahan, ed, The Catholic Case for Contraception 174 (MacMillan, 1969). It pays a great deal of attention to the impairment of the credibility of the magisterium that would result if contraception were declared to be morally licit. Prudential arguments based on this concern-which are non-epistemic-are a little difficult to separate from 
document has addressed the same concern. Common good is the standard criterion for normative decisions; it has no place in epistemic judgments.

2. The requirement of celibacy is constitutive for a priest. The Code of Canon Law says "Persons who are in holy orders invalidly attempt marriage" (can. 1087). There is discussion in some circles about whether priests are bound to obey this requirement. But, given its constitutive form, there is nothing to obey. Unless this canon is repealed or dispensed from, a priest who goes through a marriage ceremony is not only disobedient, he is single.

3. Marriage annulments are strictly epistemic. They determine that the relationship between the parties affected was in fact not a marriage. But there is a good deal of literature suggesting that considerations of common good or individual hardship-normative considerations-enter or ought to enter into the decisions of the tribunals. ${ }^{42}$

4. The question of the orthodoxy of a theologian's teaching would seem to be primarily epistemic. If he teaches that $X$ is the case, a finding that $X$ is not the case would seem to be a sine qua non of any proceeding against him for the teaching. But theologians generally perceive such proceedings as being from the outset accusations of wrongdoing - that is, of violating normative standards. And, indeed, those who set such proceedings in motion seem to give the accused good reason to regard them in that way. ${ }^{43}$

5. The serious question regarding the ordination of women is epistemic: If the rite of ordination is duly performed on a woman, will she then be a priest? The pope, by saying that the church is not authorized to ordain women, rather than that it is not capable of doing so, has at least somewhat

\footnotetext{
arguments based on the epistemic privilege of the magisterium, but the prudential arguments certainly play a part. A number of the dissenting arguments in the above volume reflect similar prudential concerns: It is Humanae Vitae, ill-reasoned as it is, that will impair the credibility of the magisterium. Also non-epistemic are arguments based on the problem of overpopulation. See, for example, Adrian Hastings, The Faces of God 4246 (Orbis, 1976). On the other hand, arguments based on the effect of the anticontraceptive teaching on the spiritual lives of individuals may be epistemic: moral principles may be known through experience.

42. See John T. Noonan, Jr., Power to Dissolve (Harv U Press, 1972). The epistemic question in a marriage case is ontological rather than moral, so the experience of hardship cannot have the same relevance it has in the case of contraception.
}

43. See, for example, T.J. Reese, Inside the Vatican 248-63 (Harv U Press, 1996). 
confused the issue. ${ }^{44}$ His own pronouncement is epistemic, but the pronouncement he attributes to the Lord is normative where it might have been constitutive. At any rate, much of the opposition has been politically structured in forms that make no sense unless the pronouncement objected to is normative.

6. The bishop of Lincoln, Nebraska recently proclaimed that all Catholics who belonged to certain organizations and did not - quit by a certain day would be automatically excommunicated on that day. ${ }^{45}$ Under the canon law, such a pronouncement is constitutive: no further action is necessary to make excommunicates of the people to whom it applies. ${ }^{46}$ On the other hand, by long tradition it does not apply to anyone whose conscience is clear-in this case, to anyone who believes there is nothing wrong with belonging to the organizations in question. ${ }^{47}$ But much of the polemic aroused by the pronouncement, both pro and con, has treated it as a normative pronouncement fortified with a severe punishment.

\section{DISSENT AND OPPOSITION}

When the constituted authorities have determined that such and such is the case, those who continue to insist that it is not the case, and to act accordingly, are said to "dissent." Consideration of the place of this kind of dissent in the life of the church relates necessarily to the epistemic. Dissent from a constitutive pronouncement would be unavailing. We can approve or disapprove of such a pronouncement, but if it is within the authority of its author, it will have its effect whether we approve or not. For instance, a person who does not like daylight saving time will generally not adopt a dissenting version of what time it is. He will admit that it is two o'clock even though he thinks it should be one.

44. Origins, xxiv 49 (1994): "The church has no authority whatsoever to confer priestly ordination on women." "The real reason is that ... Christ established things this way."

45. Origins, $25 \mathrm{xxv}$ (1996).

46. Code of Canon Law, can. 1314.

47. On the traditional attitude, see the story of Sverre, King of Norway, as recounted in Rosalind Hill, Theory and Practice of Excommunication in Medieval England, 42 History 1 at 5-6 and notes at xlii (1957). The tradition, of course, is a mere application of the broader principle that an unjust law is not binding in conscience. 
Dissent from a normative pronouncement would be meaningless. Those who disapproved of General Butler's "woman of the town" ordinance expressed their approval not by pointing out that women who insulted Union soldiers were not necessarily prostitutes-which the general already knew-but by vilifying the general, and eventually having him removed. Similarly, if lawmakers wish to adjust the affairs of insolvent banks by means of a conclusive presumption that any director of such a bank is aware of the insolvency, a person who thinks a particular director was not aware of the insolvency of a particular bank will not express dissent from the conclusive presumption; he will attempt to change the rule by which the presumption was created. To be sure, it is possible to claim that a constitutive pronouncement is beyond the authority of its author, or that a normative pronouncement is unjust. Either claim would support a denial of the fact asserted in the pronouncement. But that would not be the assertion dissented from. The dissent would be from the implied assertion of authority on the one hand, of justice on the other. These assertions are not constitutive or normative; they are epistemic. So, whether dissenting Catholics are marrying before justices of the peace, receiving Communion without resigning from Planned Parenthood, or denying the Virgin Birth, their dissent is from exercises of epistemic authority on the part of the church.

Dissent from an exercise of epistemic authority will presumably rest on a claim of the dissenter to be better informed than the person or persons in whom the authority resides. Going back to the case of the German submarine that sank the hospital ship, the commander was justified in believing the German Admiralty because he had no reason not to. Had he known that the ship in his periscope was really a hospital ship and not a troopship in disguise, he would have had both the right and the duty to disregard his instructions from the Admiralty and allow the ship to pass.

The medieval writers who teach that Christians must follow their own consciences even if church authority says the opposite seem generally to be dealing with marriage cases in which a person is aware of the true facts but is unable to establish them in the external forum. Horace is aware that before marrying Wilma in church he was secretly married to Wanda, who is still living. But the ecclesiastical judge does not believe his testimony about 
the secret marriage, and orders him to cohabit with Wilma. He must disobey the judge, because he knows that obedience will be adultery. ${ }^{48}$

This of course is an easy case. The epistemic pronouncement of authority concerns a matter of strict empirical fact on which the dissenter has first hand information, while all the information available to the author of the pronouncement is second hand. In the submarine case, by contrast, the author of the pronouncement in question-someone in the German Admiralty-would be likely to have better sources of information than the commander of the submarine.

But the epistemic pronouncements of authority do not derive their binding force merely from the trustworthiness of the sources of information on which they are based. While they cannot bind anyone who has a solid basis for recognizing that the asserted fact is not the case, they are not mere opinions or scraps of evidence to be considered for whatever they may be worth. For the person subject to them, they are privileged over other sources of information. Except for infallible pronouncements of the church, they are not absolute, but they are still not limited to their intrinsic persuasiveness. For instance, if the German submarine commander had read in the New York Times that the British were disguising troopships as hospital ships, his belief would probably not have won him an acquittal, even though the Times had better sources of information than the Admiralty, and less motivation to accept or disseminate falsehood. In fact, the court treated the commander's defense as one of superior orders, raising the epistemic privilege of the Admiralty as an answer to the question whether the commander ought to have known that the orders were unlawful.

This kind of epistemic privilege extends to belief as well as to action. Other things being equal, we will probably believe a determination by the Food and Drug Administration to the effect that a certain food additive causes cancer more readily than an article to the same effect in the New England Journal of Medicine, and we will be readier to believe that someone is a thief or a drug dealer on the verdict of a jury than on the findings of an investigative reporter. A legal obligation to believe what we are

48. C. 44, X, v, 39; Aquinas, Sentences IV, dist. 38, art 4. This citation from Aquinas is given as the authority for the supremacy of conscience over ecclesiastical authority in Richard P. McBrien, Catbolicism 1003 (Winston Press, 1980, Study Ed, 1981). 
told is the case can obviously not carry the same force as one to do what we are told to do. Still, it is not negligible.

\section{CONCLUSION}

I have attempted with this analysis to make three main points about laws in general that need to be kept in mind in considering the magisterium of the church. First, not all authoritative pronouncements to the effect that this or that is the case are epistemic in form. While some are in fact epistemic, others are normative or constitutive. This is true of the church as well as of the state. Second, although the church is more elaborately concerned with epistemic pronouncements than the state is, it is not alone in making them. The state and its instrumentalities often make epistemic pronouncements. Finally, authoritative epistemic pronouncements, whether coming from the church or from the state, have what might be called an epistemic privilege. That is, they command acceptance beyond their intrinsic persuasiveness or the learning and wit of their authors.

On the other hand, no pronouncement, however authoritative, carries an epistemic privilege against anyone who is better informed than its author. It is this principle that makes the question of the epistemic privilege of the church's doctrinal pronouncements so exquisitely subtle.

The hippopotamus's day

Is passed in sleep; at night he hunts;

God works in a mysterious way-

The Church can sleep and feed at once. ${ }^{49}$

It is easy enough to be better informed than this or that bishop or theologian, but no Christian is better informed about faith or morals than the corporate reflection of the church under the guidance of the Holy Spirit. To be sure, not all the doctrinal pronouncements emerging from this reflection are infallible-as modern polemicists have not been slow to point out. But insofar as they are authentic, they have a high epistemic privilege. They can be qualified or even superseded as the underlying reflection

49. T.S. Eliot, The Hippopotamus in Selected Poems 40 (Faber, 1954). 
continues, and the church continues to experience history in dialogue with the world. But I do not think they can be replaced by equally authentic pronouncements of opposite effect.

With these principles in mind, we can venture a few conclusions about the obligation of the individual Catholic toward the epistemic pronouncements of church authorities. I suggest the following:

1. Trying to correct epistemic pronouncements through political action is inappropriate. The ability to organize political opposition to a pronouncement is not a sign of being better informed than the author, and therefore no amount of political opposition is a reason for changing or rejecting the pronouncement. To be sure, some pronouncements are politically motivated. To the extent that they are, they are inauthentic, and can be attacked on that ground. Such an attack is not political.

2. I believe it is also inappropriate to affirm the exact opposite of a concededly authentic pronouncement: "The official teaching of the church is that $\mathrm{X}$ is the case, but in my opinion, not-X is the case for the following reasons." An assertion in that form is a claim to be better informed than the corporate reflection of the church, and therefore, as I have indicated, is impermissible.

3. It is quite permissible, however, to argue that a certain pronouncement is not in fact authentic-that it comes not from the corporate reflection of the church, but from this or that prelate, theologian, or deliberative body, a source less well-informed than the person making the argument. Note that the question whether the pronouncement is true or false is not strictly relevant to such an argument. It is a threshold argument, calculated to overcome the epistemic privilege of the pronouncement and so open the way for a subsequent argument that it is false.

Note also that an argument of this kind is legal before it is theological. The actual author of the pronouncement in question (or any other pronouncement for that matter) is a natural person, and the question whether the acts or utterances of a natural person are to be attributed to an institution is always and everywhere legal. The divine guidance of the corporate witness of the church does not make it any less true that the discernment of that corporate witness depends on legal analysis of the acts of natural 
persons. Even the absolute epistemic privilege that Catholic doctrine attributes to certain pronouncements of the pope is derivative from the place of such pronouncements in the corporate witness of the church: "The Roman pontiff, when he speaks ex catbedra ... is endowed with that infallibility with which the Divine Redeemer has willed that His church ... should be equipped." 50

The legal analysis of the church's epistemic pronouncements presents unique subtleties that cannot be taken up here. But the beginning of wisdom on the subject is to recognize that it is legal analysis and not something else.

4. Even if a pronouncement is authentically that of the church, it is not necessarily fixed for all time in the deposit of revealed truth. As I have suggested, it can be qualified or superseded as the church continues to reflect on its experience of the Gospel. This too is a legal process of great subtlety that cannot be taken up here. It involves the emergence of a people's law from its history, and whole schools of jurisprudence are devoted to it. ${ }^{51}$ In the case of the church it is particularly subtle because the historical process is guided by the Holy Spirit. ${ }^{52}$ But the guidance is primarily applicable to the process itself, and only secondarily to the legal pronouncements derived from it. That derivation is still a matter of legal analysis.

5. Authenticity with its accompanying epistemic privilege is not a quality that pronouncements either possess fully or do not possess at all. The authors of such pronouncements have different positions in the governance of the church, and are differently anchored in the tradition whose authenticity is the source of their own. The pronouncements themselves, therefore, have different degrees of authenticity, and are open to different combinations of flat out negation and qualification or supersession. Finding just the combination to go with any

50. First Vatican Council, 1870. Documents of the Christian Church, Henry Bettenson, ed, 383 (Oxford U Press, 1947).

51. For a judicious treatment of the subject, see John T. Noonan, Jr., The Alliance of Law and History in Persons and Masks of the Law 152-67 (Farrar, Straus and Giroux, 1976).

52. Friedrich Karl von Savigny, the founder of the Historical School of Jurisprudence, thought of law as an emanation of the Volksgeist, the spirit of a people. Using this terminology, one might say that the Holy Spirit is the Volksgeist of the church. 
given pronouncement is another task that belongs in large part to legal analysis.

The object of these conclusions, and, indeed, of this whole article is to stake out a claim for legal analysis in a polemical context in which it has been sadly lacking. I am not suggesting that law should replace theology-God forbid! But it is all too easy to cut our particular theological reflections loose from the slow and not altogether predictable development of the corporate experience of the People of God-to let them float in the air or to attach them to one of the world's ephemeral hitching posts. It is easy also to make the opposite mistake of clinging to the institutional church with a mindless authoritarianism that stultifies any serious participation in its ongoing corporate reflection, or indeed any theological reflection at all. To avoid both errors requires knowing how to work creatively within the framework of a corporate body, and how to work in due but no more than due subordination to constituted authority. For the purpose, it requires a more versatile set of legal categories than have yet been brought to bear on the magisterium. I hope here to have taken a step or two toward developing such a set. 
